\title{
Jens-Christian Wagner, Produktion des Todes. Das KZ Mittelbau-Dora (Production of Death: The Concentration Camp Mittelbau-Dora), 2nd ed. (Göttingen: Wallstein Verlag, 2004).
}

\section{Christiane Grieb, University College London}

World War II was not only a competition between nations' military strategies. More than any war before, it featured technological trickery and the foiling and outmaneuvering of the other side's armed forces by new inventions. The most spectacular feats of scientists became as important to victory as military tactics were for the outcomes in the battlefields. As the Third Reich teetered on the verge of defeat, the Nazis exerted a gargantuan effort to plan, execute and speedily implement the secret underground serial production of the first long-range missile, which would become known as vengeance-weapon (V 2). From spring 1944 through the liberation in April 1945, prisoners of war, and civilians deported from occupied countries and criminals sentenced to serve hard labor were held in the concentration camp complex of Mittelbau-Dora to provide a cheap and replaceable "human resource" of forced labor for the secret missile program of the Nazi state. For his book Produktion des Todes. Das KZ Mittelbau-Dora (Production of Death: The Concentration Camp Mittelbau-Dora), German historian JensChristian Wagner meticulously researched how this camp complex was planned and executed at the cost of tens of thousands of victims of a harsh forced labor regime in the Mittelwerk, the underground production site of death. 
Based on Wagner's $1999 \mathrm{PhD}$ dissertation at the GeorgAugust-Universität Göttingen in Germany, the book was first published in 2001 and a second edition followed in 2004. Although it is the only complete historical study from the creation of the Buchenwald subcamp of "Dora" to the independent industrial-labor camp complex of Mittelbau, Produktion des Todes has not generally been reviewed in Englishspeaking journals. The main reason is certainly the fact that the book has not yet been published in English and that such an effort would demand the translation of an impressive 688 pages. But this should be no reason to neglect this meticulous account of a national socialist slave labor enterprise in the study of Nazi Germany. As such Wagner's book is a contribution to the study of concentration camp history, national socialist camp economies, and the bystander society (Tätergesellschaft) of the Third Reich, as well as organized Nazi war crimes.

Indeed, Wagner's book also offers a much more differentiated account of the underground production facilities than previous publications, which generally focus on the often mystified V-weapons and their production, as well as the myths around the "buzz-bombs" that terrified thousands of Londoners. Rather than writing another account of the "legendary" underground "rocket" production as the origin of the space craft era for the United States, Wagner clearly identifies the forced laborers as the main victims of that "rocket" project and their deaths as the main product of this industrial complex of underground production site and above-ground concentration camp suffering.

In order to make these arguments, Wagner consulted an immense number of primary and secondary sources, including 
textual documents found in more than twenty archives in Germany and abroad, and witness interviews. In eight chapters, he critically incorporates this historical information to support his major assertion that the concentration camp was intended, from the beginning, as a work camp, and proven so by its incorporation in the regional economy and the ways in which the camp prisoners were exploited and replaced as a human labor source. Wagner's work thus challenges much existing concentration camp historiography, demonstrating that camps were not only extermination camps but also work camps for armament production.

In his introductory two chapters, Wagner summarizes major historiographical developments in the scholarship of concentration camps generally, and on the discourse relevant for Mittelbau-Dora camp specifically. The extension of the discussion to the economic purposes of Mittelbau-Dora as one of the many concentration camps run by Himmler's Protection Squadron (Schutzstaffel, SS-) for the SS Economic and Administrative Main Office (SS-Wirtschaftsverwaltungshauptamt, $S S-W V H A$ ) prepares the reader for the major discussion of the crime scenes (Tatort) of slave labor and their relationship to the Nazis' relocation projects in the third chapter.

Tracing local preconditions, such as the development of the regional economy based on ammunition and rearmament supply production back to the mid 1930s, Wagner is also able to establish the context for the acceptance of a huge concentration camp enterprise among the bystander population later in his discussion. The use of contracted Poles and forced labor in local industries helped to accustom the local population to the sight of prisoners and foreigners in work camps found in the region. 
Although these were mostly corporate housing projects, they nonetheless prepared the German civilians to accept easily the changes that the gargantuan relocation projects of war - in this case, important armament productions - would create for the region from 1943 on.

In the fourth chapter, Wagner's meticulous studies of archival resources and historical documents are the foundation of his argument that Mittelbau-Dora was created out of an emergency relocation of the rocket facilities in Peenemünde and out of the by then obsessive pursuit of underground relocations (Untertageverlagerungswahn) in the whole Reich, which only worsened when airplane and fighter jet production sites became the focus of allied bombings in 1943 and 1944 (pp. 106-18). Mittelbau-Dora, Wagner argues, was a "deadly construct" (tödliche Konstruktion, p.181), a play on words that captures the history of the camp and underground constructions of the relocated rocket facilities as well as the created conditions under which prisoners worked and died. This is an original and argumentative description of the events and their implications alike that magnifies the managerial execution of slave labor in scientific armament projects of the Reich.

How the Reich Armament Ministry's desperate search for solutions under its minister Albert Speer, ${ }^{1}$ as well as the infighting over competencies and authorities with the laborproviding SS-WVHA and Himmler, competed for attention with the need to accommodate local and corporate structures for a clandestine and swift execution of the relocation projects is

\footnotetext{
${ }^{1}$ Speer was one of the major war criminals tried by the International Military Tribunal in Nuremberg 1945-46. 
excitingly narrated (pp. 194ff). Since Wagner's account is backed up by primary source study, he convincingly makes a case for the economic pursuits that dictated the terms of the armament projects. The victimization of the forced laborers, who did not need to be paid or even humanely treated, was an especially important factor. He narrates how human life was an acceptable sacrifice since it was paid by concentration camp prisoners, who could easily be replaced by transfers from any of the other 1,500 SS-run camps in the Reich.

Thus, in his first 250 pages Wagner gives ample arguments for the claim that concentration camp Mittelbau-Dora was indeed a work camp (Bau-KZ, pp. 13, 245). Initially created as a subcamp of concentration camp Buchenwald, MittelbauDora soon established its own network of over 30 subcamps, making Mittelbau-Dora an independent main camp. As the SS provided the slave labor for industrial and private enterprises, these subcamps were established near such work sites. Eventually, many subcamps were created out of these work details, a historical fact that makes a convincing argument for Wagner's claim that Mittelbau-Dora was indeed created as and remained to be a work camp.

The remaining chapters are committed to proving why and how the major product of this camp complex was death, leading to the title of Wagner's book, Produktion des Todes. A central point of focus in these chapters is the camp structure that has been extensively discussed by scholars such as Michael Thad Allen, Wolfgang Sofsky and Eugen Kogon; ${ }^{2}$ Wagner reflects on

\footnotetext{
${ }^{2}$ Michael Thad Allen, The Business of Genocide: The SS, Slave Labor, and the Concentration Camps (Chapel Hill, London: The University of North Carolina Press, 2002); Michael Thad Allen, "The Banality of Evil 
the specifics of the Mittelbau-Dora camp. The fifth chapter, entitled "Between the Dachau Model and Improvisation" ("Zwischen Dachauer Modell und Improvisation," pp. 289ff), studies the camp regime under the two camp commanders, Otto Förschner and Richard Baer. This portrayal of the camp shows to what extent work and living conditions in the camp sites were the result of the commandants' own style of authoritarian rule, and how much these conditions determined the chance of survival for the over 40,000 prisoners held in the camp complex by 1944. Baer was previously the commander of camp Auschwitz, and with the evacuation of thousands of Auschwitz prisoners to Mittelbau-Dora in January of 1945 , he took over Mittelbau-Dora from Förschner. Having hailed from an evacuated camp complex, Bear brought much of the deathcreating improvisation into the life of Mittelbau-Dora inmates, worsening their plight. At least 20,000 eventually died in the diverse armament production and to the miserable camp conditions (p. 287).

Wagner does a thorough job of depicting the relationships between a hopeless fight for winning the war, utilization of prisoners without sufficient resources, food, clothing or disease prevention, and improvisation in the running of the camps. In his own well-researched and narrative style, and with a detailed portrayal of prisoner life and decision making based on survivor testimonies, camp records, written and oral

Reconsidered: SS Mid-Level Managers of Extermination through Work," Central European History 30 (1997): 253-94; Wolfgang Sofsky, The Order of Terror: The Concentration Camp, trans. William Templer (Princeton, New Jersey: Princeton University Press, 1997); Eugen Kogon, Der SSStaat: Das System der deutschen Konzentrationslager (Frankfurt (Main): Europäische Verlagsanstalt, 1965). 
accounts of locals and comprehensive study of secondary sources, he explains how these miseries were accompanied and fueled by the desperation of the camp authorities and the increasing use of terror as the central principle of camp discipline (Terror als zentrales Ordnungsprinzip des Konzentrationslagers, p. 345). In a final analysis of the camp life, focusing especially on the camps' purposes and circumstances, Wagner illuminates that the destruction of life was not a deliberate working to death (Vernichtung durch Arbeit), as suggested by previous camp studies (e.g. Sofsky, Kogon), but that it was especially the ambivalence towards the value of the prisoners' lives that fostered a ready acceptance of death as a product of the labour utilization under the harshest of conditions (pp. 499, 500).

Finally, Wagner provides a well documented example of the ambivalence about human life and its calculated utilization in economic pursuits, which Lutz Budraß and Manfred Grieger termed a "morality of efficiency" (die Moral der Effizienz) in 1993. ${ }^{3}$ He reiterates the connection between deadly outcomes of camp lives within the SS camp hierarchies in a separate section (“Opferhierarchien? Die Häftlingsgesellschaft," pp. 395-452), and correlates it to the acceptance of camp destinies among the local population. Especially helpful is the portrayal of the societal environment of the German population, which Wagner identifies as an almost logical continuation of the economic history of the otherwise non-industrial Southern Harz region in postDepression and pre-war times. In this point, Wagner depicts an

\footnotetext{
${ }^{3}$ Lutz Budraß and Manfred Grieger, “Die Moral der Effizienz. Die Beschäftigung von KZ-Häftlingen am Beispiel des Volkswagenwerks und der HenschelFlugzeugwerke," in Jahrbuch für Wirtschaftsgeschichte 2 (1993): 89-136. 
example of an interwar generation that became receptive to any economic revitalization and that offered the Nazis a deliberate collaboration with armament production during the rearmament period. Towards the end of the war, when labor became scarce, control of human resources by the SS in this economically challenged region also extended into the labor policies for the German populace, who were ordered to work side-by-side with prisoners (Arbeitsdienstverpflichtung) in the Mittelbau-Dora complex. As for a moral assessment, the bystander mentality was further encouraged by the corporate system within which the Mittelwerk operated and hosted a well-entrenched SS labor administration for its own projects on a regional level. After the war these aspects allowed German administrators and the population alike to delegate responsibility post facto to the SS and to deny any knowledge of crimes committed. In a final review, Wagner addresses these means of justification of an unspotted conscience and comes to the conclusion that there was an interdependence between the intimidating existence of the camp in the backyard of the region and the collaboration of Germans in the maltreatment of forced labourers (wechselseitige gesellschaftliche Durchdringung, p. 580). Nonetheless, Wagner claims, there existed a deliberate self-deception about the misery of the labourers among those who made use of them. Moreover, the fact that many Germans were hired to work as foremen with prisoners in the work details or as guards, or even ordered prisoners for their own businesses, produced a co-responsibility for their plight beyond a claimed bystander status, and rather made them collaborators (Mittäter) in the maintenance of the deadly work-camp systems in their region (p. 581).

\author{
Past Imperfect \\ 16 (2010) | @ | ISSN 1711-053X | elSSN 1718-4487
}


The criticism might be made that the corporate and polycratic mechanisms that contributed to the creation of eventually over 1,500 concentration camps in the German Reich could have been given more attention; most of Wagner's energy is spent on the portrayal of camp and work life. The very short section describing the reasons for the independence of concentration camp Mittelbau-Dora from Buchenwald seems to be the right place for such context. However, Wagner successfully analyses the interdependencies and implications of national needs in a prolonged war, its increasing demands of armament production and accompanying resource shortages and its results in a local representation of the utilization of deported prisoners and concentration camp inmates as a seemingly costeffective alternative in a wartime economy. He meticulously traces the origins of the camp and the Mittelwerk Corporation to exemplify that local complicity and economic administration went hand-in-hand with the ideological and racial agendas of the Nazi state and the SS organized camp system in wartime Germany. Altogether, Wagner succeeds in analyzing the creation and existence of the Mittelbau-Dora concentration camp not as one of racist extermination policy or extermination through work policies, but as a work or labour camp for many companies in the region. Thereby he debunks, at least for the Mittelwerk and Mittelbau-Dora camp complex, another myth of the German post war recuperation with wartime complicities. The adopted belief of communal separation between concentration camp crimes and German life, on which the "We did not know" mentality was feeding in post-war Germany, is interrogated and successfully refuted. His work rather supports the opposite claim. Wagner provides ample examples of how wartime 
decision making and the routine of concentration camp life eventually permeated the German society. Thus, he effectively argues two main themes: besides the discussion of the common concentration camp themes of misery and death, he magnifies the importance of the concentration camp as human labor hub for wartime production. Beyond this aspect, he also succeeds in portraying the camp complex as an example of the German bystander mentality in a central part of Germany largely untouched by wartime combat. Wagner succeeds in convincing readers without having to resort to any populist appeals and honestly recasts propaganda as a relatively minor issue in the historicization of camp and slave labor histories.

Altogether, Wagner's voluminous work is foremost made accessible by his elegant and thoughtful, yet narrative, style. That its scholarly impact is still rather limited to local historiography and German scholarship might in part be because Wagner fails to address other works that were internationally contested at the time of writing. Here, I specifically observed an absence of any engagement with claims raised by Daniel Goldhagen in his 1996 book on the German complicity, Willing Executioners. His bibliography and footnotes, though, attest to an archival scouring of facts painstakingly pursued, and from which emerge his excellent account of a local representation of national socialist labour and camp policies. It should perhaps be noted that most of Wagner's consulted primary sources were located in Germany. Interestingly, many of the records available in German depositories were previously cleaned up, not by Germans, but by so-called exploitation branches of the Allied forces in the immediate post-war race for intelligence data. Especially those related to the missile production found great interest among all 
allies. Many of the American-seized sources, however, were only declassified at the end of the Clinton presidency, after Wagner had completed his research. Wagner instead uses available records from the war crimes branches as well as captured camp records, victim interviews, and narratives of survivor and locals and secondary histories. This is a comprehensive, almost exhaustive use of sources that produces a high stake departure

point for further historical enquiries into the history of camp Mittelbau-Dora. In his final chapters, titled "Die Erosion zivilisatorischer Werte" (The Erosion of Civilizing Values) and "Schluss" (The Conclusion), Wagner also rounds up his own interpretation of consulted historical data by providing us with a very objective historiographical discussion of histories and myths created during the Cold War from East German, West German and Allied perspectives.

Wagner's case study of the industrial camp complex of Mittelwerk-Dora not only contributes hugely to the historiography of concentration camp life and forced labour history, but his succinct tracing of local workforce management and ambivalence contributes to our understanding of the extended SS camp and sub-camp system that eventually engulfed the whole of Nazi Germany. Wagner provides readers with a historical study that can only be challenged if new resources can be identified or new approaches applied to the study of the camp's history. His work on the Produktion des Todes was an ambitious project that generated a comprehensive scholarly work that certainly enriches the discourse on the history of Nazi camps. 